\title{
Editorial
}

\section{Necesidad de cambios en El Salvador}

El impacto de los terremotos del 13 de enero y 13 de febrero impone el desafío de efectuar una serie de cambios al modo en que se ha venido gestionando el país en las últimas décadas. Todo parece indicar que se está fraguando un cierto consenso en torno a esa necesidad. El gobierno, al hacerse cargo de las tesis del documento Elementos para la reconstrucción y el desarrollo de El Salvador. Una contribución desde la sociedad civil, elaborado por la Comisión Nacional de Desarrollo, prácticamente está avalando oficialmente la búsqueda de propuestas de reforma económica, social y medioambiental. Este editorial pretende contribuir a la discusión sobre los problemas fundamentales del país, así como a sus posibles vías de solución. Realidad le toma la palabra, dando su contribución a ese diálogo.

Para comenzar, es necesario arrancar la discusión examinando cuál era la situación de El Salvador antes de los dos terremotos. Una primera característica de esa situación es la desarticulación estructural entre sus tres ejes económicos fundamentales, es decir, entre la agricultura, la industria y el sector financiero. Del deterioro del sector agrícola se ha hablado hasta la saciedad, al igual que del rezago del aparato industrial. También se ha insistido en la expansión del sector financiero, misma que ha llevado a la concentración de millonarias sumas en manos de las familias que controlan los bancos, las compañías de seguros y las empresas de pensiones. Aquí conviene insistir en que la expansión del sector financiero ha sido a costa de los otros dos sectores económicos, ahogados por las deudas, las altas tasas de interés, la ausencia de inversiones y el atraso tecnológico. 
En segundo lugar, vinculado a lo anterior, está la precariedad social que afecta a la mayor parte de la población. Esta precariedad guarda una estrecha relación con la incapacidad del aparato productivo para generar niveles adecuados de empleo, tanto desde el punto de vista de puestos de trabajo como en cuanto a salarios acordes con las necesidades básicas de los salvadoreños. Desempleo, subempleo y salarios bajos se traducen en dificultades permanentes para acceder a una vivienda digna y segura, así como a niveles adecuados de salud y educación.

En tercer lugar, se tiene el complejo problema de la vivencia social, en sus diversas expresiones: crimen organizado, delincuencia común y violencia cotidiana de todo tipo. Quizás sea demasiado afirmar que la violencia es el resultado directo de la precariedad social y la pobreza, pero lo que no puede ponerse en duda es que ambas son caldo de cultivo para el malestar y la agresividad sociales.

En quinto lugar, se tiene el problema de la ruptura entre la sociedad, la política y el aparato estatal. Esta ruptura consiste en que las demandas sociales no encuentran la intermediación requerida en el sistema político, mientras que, por su lado, el Estado no tiene la capacidad ni los recursos idóneos para atender las demandas sociales fundamentales. Es por este "fracaso de la política" que se abren en el país las puertas al desencanto, la apatía y, en situaciones extremas, a la protesta violenta de quienes no encuentran eco estatal a sus demandas.

Finalmente, un uso "desordenado" de los recursos naturales y del espacio territorial. Las manifestaciones más notorias de ello son, por un lado, la lógica que predomina en la construcción de viviendas urbanas (aunque también rurales) y, por otro, la cultura generalizada del abuso sobre los recursos naturales.

Los anteriores son los ejes que han caracterizado al país hasta antes del 13 de enero. La pregunta que hay que hacerse es la siguiente: ¿Cómo es que llegó a configurarse un país con las características descritas?

Una primera respuesta puede ser que fue por voluntad divina. Emparentada con ella, puede darse la respuesta de que fue por imposición de la naturaleza, con sus leyes inexorables. Ambas ideas son sumamente peligrosas, en tanto pueden traducirse en un peligroso fanatismo acerca de lo que le espera a El Salvador y acerca de lo que se puede hacer para cambiar un ordenamiento social, económico y medioambiental excluyente de la mayor parte de la población y depredador de los recursos naturales.

Más bien, dejando para una discusión posterior tanto el complejo tema de la "voluntad divina" como el no menos complejo tema de la "inexorabilidad de la naturaleza", se puede proponer una respuesta a la anterior interrogante que permita hacer algo para cambiar el ordenamiento socioeconómico y medioambiental prevaleciente en el país. La respuesta aludida es la siguiente: El Salvador llegó a configurarse con las características apuntadas debido a una inadecuada gestión económica, social y medioambiental. 
Esta gestión, que se podría calificar de "tradicional", ha girado en torno a los siguientes ejes: (a) débil e ineficiente entramado institucional. Ello ha dado pie tanto a la discrecionalidad en la toma de decisiones como a la corrupción en la estructura del Estado; (b) voracidad empresarial que no ha conocido límites y que se ha traducido en una explotación creciente de la fuerza de trabajo y de los recursos naturales; (c) fracaso de la clase política en su función de intermediación sociopolítica, lo que ha dado lugar a brotes de descontento social que amenazan la estabilidad del país; (d) políticas públicas centralizadas y burocráticas que no sólo han sido ineficaces para responder a las necesidades ciudadanas, sino que, además, han estado orientadas casi exclusivamente a favorecer a determinados grupos de poder económico; (e) bajos niveles de organización y participación sociales, mismos que han llevado a la mayor parte de la población a ser un mero receptor pasivo de las decisiones emanadas del aparato estatal, muchas veces bajo la presión de la gran empresa privada.

Si algo no puede ponerse en duda es que los terremotos sacaron a luz estas debilidades en la gestión económico-social y medioambiental vigente en el país. $\mathrm{Su}$ impacto plantea la necesidad y la oportunidad de un cambio en la misma. ¿Cuáles son las opciones que se presentan?

Una de ellas es la propuesta elaborada por la Comisión Nacional de DesarroIlo, la cual apunta, ante todo, a la descentralización y al ordenamiento territorial como mecanismos clave pare el cambio. "Ahora es el tiempo de la descentralización" —dice el documento de la citada Comisión-. "La articulación entre el gobiemo nacional y los gobiernos municipales es un requisito para la reconsIrucción". Asimismo, "la reconstrucción debe impulsarse con una visión de ordenamiento territorial y de reorganización política-administrativa que tienda a la integración de la geografía económica y humana”.

Una segunda iniciativa es la del FMLN, titulada Estrategia de reconstrucción y de transición al desarrollo, la cual tiene como meta la creación de una "nueva sociedad", que es "necesaria para enfrentar la emergencia y para contrarrestar y superar el egoísmo, el endiosamiento del dinero a costa del hambre de los demás, los cuales son antivalores para el ser humano, propios del capitalismo".

Ambas propuestas, aunque interesantes, pecan, la una por defecto y la otra por exceso. Mientras que el documento de la Comisión Nacional de Desarrollo pretende contribuir a la "superación de algunos problemas estructurales del pasado", sin abordar el problema de la estructura de la propiedad y del deterioro institucional, el FMLN abandera una postura amarrada a un enfoque ideológico, que irremediablemente hará que las élites empresariales —-soliviantadas por las empresas mediáticas más poderosas - se pongan a la defensiva ante la posibilidad de cualquier cambio, por mínimo que sea.

Más allá de las discusiones ideológicas, el país urge de cambios que vayan más allá de la descentralización y del ordenamiento territorial - con todo lo 
importante que ambas cosas puedan ser-. Estos cambios, aunque drásticos en algunas áreas, no tienen por qué inscribirse en un horizonte socialista o revolucionario. Simplemente, basta con una buena dosis de sentido común y de razonabilidad para entender que El Salvador no puede continuar como hasta ahora, pues de seguir tal cual las tan preciadas riquezas se verán amenazadas, como en el pasado, por desbordes sociales que darán al traste con las mejores expectativas.

¿Cuáles pueden ser los ejes básicos de un nuevo modelo de gestión para El Salvador? A modo de propuesta tentativa, se pueden apuntar los siguientes elementos: (a) Ese nuevo modelo de gestión debe contribuir a - y apoyarse en- una reforma en la estructura de la propiedad (empresas, bancos y tierras agrícolas); (b) Debe articular al sector financiero con la agricultura y la industria, fomentando las inversiones de mediano y largo plazo en esos sectores productivos; (c) Debe apoyarse en un sólido entramado institucional; (d) debe concretarse en un conjunto de políticas públicas diseñadas para atender los desafíos de un país amenazado por "riesgos" naturales, económicos y sociales; (e) Debe dar paso a una "cultura del riesgo y la seguridad", que suponga para todos los habitantes del país hacer lo que se pueda para no ser una "amenaza" para los demás, al tiempo que permita trabajar por erradicar las amenazas existentes; (f) Debe fomentar la organización y la participación sociales, con miras a potenciar las energías colectivas en el ámbito local y (g) Debe contribuir a una renovación de la clase política, sin la cual las posibilidades de cambio en el país se verán obstaculizadas por las inercias y los vicios de unos partidos y líderes que no tienen más propósito que salvaguardar sus propios intereses. 